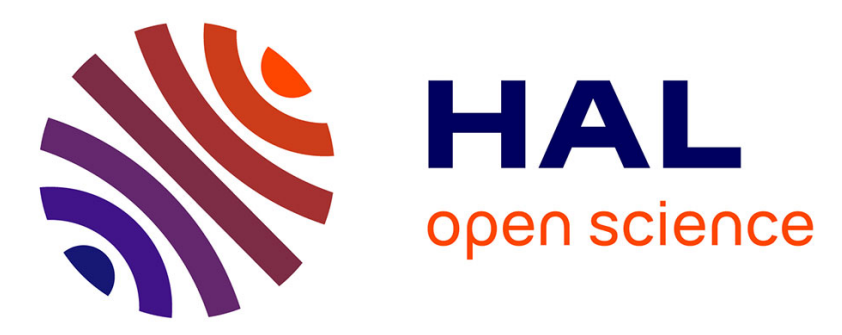

\title{
Contamination of marine fauna by chlordecone in Guadeloupe: evidence of a seaward decreasing gradient
}

Charlotte R. Dromard, Mathilde Guéné, Yolande Bouchon, Soazig Lemoine, Sébastien Cordonnier, Claude Bouchon

\section{- To cite this version:}

Charlotte R. Dromard, Mathilde Guéné, Yolande Bouchon, Soazig Lemoine, Sébastien Cordonnier, et al.. Contamination of marine fauna by chlordecone in Guadeloupe: evidence of a seaward decreasing gradient. Environmental Science and Pollution Research, 2017, 25, pp.14294-14301. 10.1007/s11356017-8924-6 . hal-01512709

\section{HAL Id: hal-01512709 https: / hal.sorbonne-universite.fr/hal-01512709}

Submitted on 24 Apr 2017

HAL is a multi-disciplinary open access archive for the deposit and dissemination of scientific research documents, whether they are published or not. The documents may come from teaching and research institutions in France or abroad, or from public or private research centers.
L'archive ouverte pluridisciplinaire HAL, est destinée au dépôt et à la diffusion de documents scientifiques de niveau recherche, publiés ou non, émanant des établissements d'enseignement et de recherche français ou étrangers, des laboratoires publics ou privés. 
1 Contamination of marine fauna by chlordecone in Guadeloupe: evidence of a seaward

3 Charlotte R. Dromard *, Mathilde Guéné, Yolande Bouchon-Navaro, Soazig Lemoine,

4

Sébastien Cordonnier, Claude Bouchon

5

6 UMR BOREA, CNRS 7208 - MNHN - UPMC - UCBN - IRD 207, Laboratoire d'excellence

7 «CORAIL », DYNECAR, Université des Antilles, Campus de Fouillole, 91157 Pointe-à-Pitre,

$8 \quad$ Guadeloupe-cdromard@univ-ag.fr

9

$10 *$ Author to whom correspondence would be addressed. Charlotte Dromard, UMR BOREA-

11 DYNECAR, Université des Antilles, Campus de Fouillole, BP 592, 97159 Pointe-à-Pitre.

12 Phone: +590 590483 011; Fax: +590 590483 283; email: cdromard@univ-antilles.fr

13

14 


\section{Abstract}

16 Chlordecone is an organochlorine pesticide, used in the Lesser Antilles from 1972 to 1993 to 17 fight against a banana weevil. That molecule is very persistent in the natural environment and ends up in the sea with runoff waters. The objective of the present study is to evaluate the level of contamination in several trophic groups of marine animals according to their distance from the source of pollution. Samples of suspended matter, macroalgae, herbivorous fishes,

21 detrivorous crustaceans, zooplanktivorous fishes, first and second order of carnivorous fishes and piscivorous fishes have been collected in two sites, located downstream the contaminated sites (Goyave and Petit-Bourg), in three marine habitats (coastal mangroves, seagrass beds located $1.5 \mathrm{~km}$ from the shoreline and coral reefs at $3 \mathrm{~km}$ offshore). Animals collected in mangroves were the most contaminated (mean concentrations: $193 \mu \mathrm{g} . \mathrm{kg}^{-1}$ in Goyave and 213 $\mu \mathrm{g} . \mathrm{kg}^{-1}$ in Petit-Bourg). Samples from seagrass beds presented intermediate concentrations of chlordecone (85 $\mu \mathrm{g} \cdot \mathrm{kg}^{-1}$ in Goyave and $107 \mu \mathrm{g} \cdot \mathrm{kg}^{-1}$ in Petit-Bourg). Finally, samples from coral reefs were the less contaminated ( $71 \mu \mathrm{g} \cdot \mathrm{kg}^{-1}$ in Goyave and $74 \mu \mathrm{g} \cdot \mathrm{kg}^{-1}$ in Petit-Bourg). Reef samples, collected $3 \mathrm{~km}$ offshore, were two to three times less contaminated than those collected in mangroves.

Key words: chlordecone, trophic food-web, inshore-offshore gradient, marine fauna, 
41 Chlordecone is an organochlorine pesticide, used from 1972 to 1993 in the Lesser Antilles, to fight again the banana weevil. The manufacturing of this chemical (commercialized as Kepone ${ }^{\circledR}$ and then as Curlone ${ }^{\circledR}$ ) was first done in Virginia and stopped in 1975, when workers from the site of production began to show severe and diverse pathologies associated to their exposure. Due to the sewage system of the factory, the local environment and wildlife was also impacted (Epstein 1978; Huff and Gerstner 1978). In the French West Indies, the use of this chemical however continued until 1993. As a consequence, approximately 6200 hectares are moderately to heavily polluted by chlordecone in Guadeloupe (Cabidoche and Lesueur Jannoyer 2011), which represents about 25\% of the land surface used for agriculture. Chlordecone is a very persistent molecule in the environment with a half-life estimated to 600 years (Cabidoche et al. 2009).

In Guadeloupe, banana plants grow in the southern part of Basse-Terre (one of the two islands of Guadeloupe), which is mountainous and, as a consequence of tropical humid weather, characterized by intense rainfall events. Organochlorine molecules are hydrophobic and adsorbed onto organic matter of the soil. With the erosion of soil particles, desorption phenomena, slow solubilization and infiltration processes, these compounds reach runoff and ground waters that end up directly into the sea (Cattan et al. 2006; Coat et al. 2006; Cabidoche et al. 2009).

Since 2003, several samplings surveys have been conducted in Guadeloupe to evaluate the level of contamination by chlordecone of some species of fishes, crustaceans and mollusks (Bouchon and Lemoine 2003, 2007; Bertrand et al. 2013; Dromard et al. 2016a,b). In 2008, the French food and safety authorities lowered the maximal residue limit (MRL) for chlordecone, authorized for human consumption and commercialization of sea products, from 200 to $20 \mu \mathrm{g} \cdot \mathrm{kg}^{-1}$ of wet weight and regulated the fishing activities around the island. The 
most contaminated marine areas, located downstream of the banana plantations, are now totally closed to fishing activities. The boundary areas are classified as areas of fishing restrictions in which it is not possible to fish a list of targeted species. These rules have been established to protect the health of the local population, especially because seafood represents a large part of the Caribbean food trade.

Studying the evolution of pollution within an inshore-offshore gradient, with different habitats and different species in the trophic food-web, is necessary to understand their dispersion mechanism. Few studies have been conducted to evaluate the dispersion of pesticide in marine environment with an inshore-offshore gradient (Rato et al. 2006; Briand et al. 2004; Dromard et al. 2016b). Organochlorine pollution in marine food-webs has been studied in mangroves (Paez-Osuna et al. 2002; Bayen et al. 2005), seagrass beds (Haynes et al. 2000; Bouchon et al. 2016) and coral reefs (Glynn et al. 1995; Haynes and Johnson 2000) but few works analyzed the dynamics of transfer of an organochlorine contamination in the continuum "mangrove-seagrass beds-coral reefs" (Schaffelke et al. 2005). The degradation of these three interlinked habitats has dramatic ecological and economical consequences (Wilkinson and Salvat 2012).

In the present study, we examined the level of contamination in several trophic groups of marine animals in relation with to their distance from the source of pollution. Concentrations of chlordecone have been measured in three marine habitats: mangroves, seagrass beds and coral reefs.

\section{Materials and methods}

Study sites

Two study sites (Goyave and Petit-Bourg) were chosen in the eastern coast of Basse-Terre in Guadeloupe (Fig.1). These two sites are located in an area of fishing restriction due to their 
position downstream the contaminated rivers and agricultural plots. These two sites include three types of marine habitats: coastal mangroves, seagrass beds (located approximately at 1.5 $\mathrm{km}$ from the coast) and coral reefs (around $3 \mathrm{~km}$ offshore). Depths were comprised between 1 $\mathrm{m}$ in mangroves and $5 \mathrm{~m}$ in coral reefs ecosystems.

\section{Sample collection and preparation}

The sampling survey was carried out from January 2014 to February 2015. For this study, 205 samples were collected, 113 at Goyave and 92 at Petit-Bourg (Tables 1 and 2). Macroalgae, fishes and crustaceans were collected by hand, spearfishing or using nets in seagrass beds and mangroves. Fishes and crustaceans were clustered in trophic groups: detritivorous crustaceans (Crust Det), herbivorous fishes (Fish HB), zooplanktivorous fishes (Fish PK), first order carnivorous fishes (Fish CA1: invertebrate feeders), second order carnivorous fishes (Fish CA2: invertebrates and fish feeders) and piscivorous fishes (Fish PV: fish feeders). Each sample was rinsed, weighted to insure the minimal quantity required for chlordecone analysis (10g wet weight) and frozen $\left(-18^{\circ} \mathrm{C}\right)$ until analyses.

For sampling the suspended matter, seawater was collected in the three habitats of each site in plastic drums. Water was then filtered at the laboratory on Whatman GF/F 47mm filters.

\section{Chlordecone extraction and analysis}

The laboratory Labocea conducted the quantitative analyses of chlordecone. Molecules of chlordecone were extracted from homogenized samples tissues with a solution of organic solvents (hexane-acetone) and turned into chlordecone hydrate (hydrosoluble) in the presence of soda. The aqueous phase was rinsed with hexane to eliminate fats. Chlordecone was then reassembled in acid conditions, extracted with a solution of hexane and acetone. Concentrations of chlordecone were quantified with liquid chromatography coupled to mass 
spectrometry in tandem (UPLC-MS/MS). Chlordecone was extracted following the method

116 recommended by ANSES (“Agence nationale de sécurité sanitaire de l'alimentation, de

117 l'environnement et du travail", French organization in charge of the sanitary security). The

118 lower limit of quantification with this method was $1 \mu \mathrm{g} \cdot \mathrm{kg}^{-1}$ and the concentrations of

119 chlordecone were expressed in $\mu \mathrm{g} \cdot \mathrm{kg}^{-1}$ (wet weight).

120

121 Statistical analysis

122 Shapiro-Wilk's tests attested of the non-normality of data distribution. Then, concentrations

123 of chlordecone were compared between types of habitat (mangrove, seagrass beds and coral

124 reefs) with Kruskal-Wallis tests. All statistical analyses were performed using the software 125 package $\mathrm{R}$.

127 Results

128 Concentrations of chlordecone according to the habitats

129 Concentrations of chlordecone measured in this study varied from $1 \mu \mathrm{gg}^{-1} \mathrm{~g}^{-1}$ (the limit of 130 quantification) to $1034 \mu \mathrm{g} \cdot \mathrm{kg}^{-1}$. Concentrations of chlordecone were significantly different

131 between the three types of habitats at Goyave $\left(X^{2}=18.9, \mathrm{p}<0.001\right)$ and at Petit-Bourg $\left(\mathrm{X}^{2}=5.5\right.$, $132 \mathrm{p}<0.05$ ), and an inshore-offshore gradient of contamination was found (Fig.2). Samples 133 collected in mangroves were the most contaminated with a mean concentration of 134 chlordecone equal to $193 \mu \mathrm{g} \cdot \mathrm{kg}^{-1}$ at Goyave and $213 \mu \mathrm{g} \cdot \mathrm{kg}^{-1}$ at Petit-Bourg. Marine organisms 135 sampled in seagrass beds presented intermediate concentrations of chlordecone $\left(85 \mu \mathrm{g}^{-\mathrm{kg}^{-1}}\right.$ at 136 Goyave and $107 \mu \mathrm{g} \cdot \mathrm{kg}^{-1}$ at Petit-Bourg). Finally, vegetal and animal samples from coral reefs 137 were the less contaminated $\left(71 \mu \mathrm{g} . \mathrm{kg}^{-1}\right.$ at Goyave and $74 \mu \mathrm{g} \cdot \mathrm{kg}^{-1}$ at Petit-Bourg).

139 Concentrations of chlordecone according to the trophic group 
140 The level of contamination according to the habitat was studied for the different categories of

141 samples independently. At Goyave, a decreasing gradient of contamination was found for four

142 trophic groups: suspended matter $\left(X^{2}=6.0, p<0.05\right)$, macroalgae $\left(X^{2}=8.9, p<0.001\right)$,

143 detritivorous crustaceans $\left(X^{2}=6.7, p<0.05\right)$, second order carnivorous fishes $\left(X^{2}=5.7, p<0.05\right)$

144 and planktivorous fishes $\left(X^{2}=4.7, p<0.05\right.$, Fig.3). The concentrations of chlordecone were not

145 significantly different according to the habitat for the herbivorous fishes, first order

146 carnivorous fishes and piscivorous fishes. Herbivorous fishes presented low and similar

147 concentrations in the three habitats $\left(42,19\right.$ and $10 \mu \mathrm{g} \cdot \mathrm{kg}^{-1}$ in mangrove, seagrass bed and reef

148 respectively). First order carnivorous and piscivorous fishes were highly contaminated in

149 mangrove (295 and $338 \mu \mathrm{g} \cdot \mathrm{kg}^{-1}$ respectively) but showed similar levels of contamination in

150 seagrass bed and coral reef (114 and $112 \mu \mathrm{g} \cdot \mathrm{kg}^{-1}$ for CA1; 154 and $134 \mu \mathrm{g} \cdot \mathrm{kg}^{-1}$ for PV).

151 At Petit-Bourg, a decreasing gradient of contamination was found for the suspended matter

$152\left(X^{2}=5.5, p<0.05\right)$, macroalgae $\left(X^{2}=10.4, p<0.001\right)$, first order carnivorous fishes $\left(X^{2}=9.7\right.$,

$153 \mathrm{p}<0.001)$ and piscivorous fishes $\left(\mathrm{X}^{2}=12.1, \mathrm{p}<0.001\right.$, Fig.4). No significant difference was

154 found for second order carnivorous fishes. For the latter, concentrations of chlordecone were

155 close between mangrove, seagrass bed and reef: 160, 203 and $160 \mu \mathrm{g}^{\mathrm{kg}} \mathrm{kg}^{-1}$ respectively.

156

157 Discussion

158 The concentrations of chlordecone measured in the present study indicate a high

159 contamination of marine organisms located in the coastal marine habitats in Guadeloupe. A

160 decreasing inshore-offshore gradient of contamination by chlordecone was found at both sites.

161 Samples collected in mangroves, located along the shore, were the most contaminated and

162 presented the highest concentrations of chlordecone measured in this study. Samples from

163 seagrass beds showed intermediate concentrations while samples from coral reefs were the 
164 less contaminated. Concentrations of chlordecone in organisms were two to three times higher

165 in mangroves than in coal reefs.

166 In previous studies on chlordecone pollution in the James River (Virginia), mean 167 concentrations of chlordecone reached $4800 \mu \mathrm{g} \cdot \mathrm{kg}^{-1}$ in zooplankton and $1700 \mu \mathrm{g} \cdot \mathrm{kg}^{-1}$ for the 168 zooplanktivorous white perch, Morone americana (Nichols 1990; Luellen et al. 2006). In

169 Guadeloupe, the highest concentration measured was $1034 \mu \mathrm{g} \cdot \mathrm{kg}^{-1}$ for Pomadasys 170 corvinaeformis, which is a first order carnivorous fish (CA1), and the concentration of 171 chlordecone in zooplankton averaged $20 \mu \mathrm{g} \cdot \mathrm{kg}^{-1}$ at Petit Bourg and $6 \mu \mathrm{g} \cdot \mathrm{kg}^{-1}$ at Goyave. In 172 comparison, the level of contamination of marine organisms in Guadeloupe appears low.

173 However, in coral reefs, located approximately at $3 \mathrm{~km}$ offshore, concentrations of 174 chlordecone measured were still three times higher than the maximal residue limit authorized 175 for human consumption and commercialization of sea products $\left(20 \mu \mathrm{g} \cdot \mathrm{kg}^{-1}\right)$. These results 176 justify the interdiction of fishing on the continental shelf located on the eastern coast of

177 Basse-Terre due to high levels of contamination by chlordecone.

178 In Florida, Glynn et al. (1995) studied the dispersion of marine fauna contamination by 179 pesticides at three sites distributed on a $5 \mathrm{~km}$ distance from the coast and found no spatial 180 variation of the level of pollution between the sites. In other studies, the dispersion of 181 organochlorine pollutants was generally demonstrated over larger distances. Rato et al. (2006) 182 studied the dispersion of a pesticide over $25 \mathrm{~km}$ of the continental shelf in Portugal. In the 183 south of New Caledonia, a decreasing gradient of pollution was also found from the coast to 184 the reef barrier on a $45 \mathrm{~km}$ distance (Briand et al. 2014). In Guadeloupe, the width of the 185 continental shelf in front of Petit Bourg and Goyave is narrow (around $5 \mathrm{~km}$ ) and exposed to 186 eastern winds and swell, which prevents the dispersion of the pollutants seaward. Indeed, 187 pollution is concentrated on this small area. 
In the present study, the gradient of contamination was analyzed for different trophic groups

189 of marine organisms. The majority of the studied trophic groups showed a decreasing gradient

190 of the contamination from the coast seaward. However, some trophic groups presented a

191 different pattern. In Goyave, the gradient of contamination was not observed for the first order

192 carnivorous fishes (CA1: invertebrates feeders) and piscivorous fishes (Table 1). These

193 species were highly contaminated in mangrove but showed similar levels of contamination in

194 seagrass bed and coral reef habitats. This could result from the mobility of these species

195 between seagrass beds and coral reefs (for example: Sphyraena barracuda). The absence of

196 gradient for some trophic groups can also be explained by the fact that a same trophic group

197 can be constituted by different species in the three habitats. Moreover, the lack of samples in

198 some habitat could lead to a bias in the comparison (for example there is a single fish species

199 of CA1 represented in the reef habitat). Still in Goyave, herbivorous fishes presented a low

200 and similar level of contamination in the three habitats (Table 1). That result could be

201 partially explained by theirs feeding patterns, as they consume macroalgae that were faintly

202 contaminated. At Petit Bourg, the gradient of contamination was not significant for the second

203 order carnivorous fishes (CA2: invertebrates and fish feeders, Table 2). The movements of

204 some of these species across the different habitats (for example: Lutjanus apodus and $L$.

205 griseus) could explain the similar level of contamination between the three habitats. These

206 movements can be carried out for dietary purposes or during post-settlement migrations

207 (Chapman and Kramer 2000; Cocheret de la Morinière et al. 2002).

208 To conclude, considering all the data combined, this study evidences a decreasing gradient of

209 the contamination by chlordecone from the coast to the coral reefs $3 \mathrm{~km}$ away from the source

210 of pollution. This spatial variation in chlordecone concentration suggests that uptake from the

211 water column is a significant source of contamination. Uptake through the trophic food web

212 via bioaccumulation is another potential source of contamination, but this hypothesis requires 
213 further investigation. Future research will evaluate the relative contribution of uptake from the

214 water column $v s$. the food web.

\section{Acknowledgements}

217 We are grateful to the anonymous reviewer for his valuable suggestions which have enabled 218 us to improve this article. This research was funded by the "Contrat de Recherche 219 Développement CHLOHAL 2" coordinated by the Préfecture of Martinique Island.

\section{References}

Bayen S, Wurl O, Karuppiah S, Sivasothi N, Kee Lee H, Obbard JF (2005) Persistent organic pollutants in mangrove food webs in Singapore. Chemosphere 61: 303-313

Bertrand JA, Guyader O, Reynal L (2013) Caractérisation de la contamination de la faune halieutique par la chlordécone autour de la Guadeloupe. Projet CarGual. http://archimer.ifremer.fr/doc/00136/24762/

Bouchon C, Lemoine S (2003) Niveau de contamination par les pesticides des chaînes trophiques des milieu marins côtiers de la Guadeloupe et recherche de biomarqueurs de génotoxicité. Rapport UAG-DIREN, 33 pp

Bouchon C, Lemoine S (2007) Contamination par les pesticides des organisms marins de la baie du Grand Culd-de-Sac Marin (île de la Guadeloupe). Rapport UAG-DIREN, 39 $\mathrm{pp}$

Bouchon C, Lemoine S, Dromard C, Bouchon-Navaro Y (2016) Level of contamination by metallic trace elements and organic molecules in the seagrass beds of Guadeloupe island. Environ Sci Pollut Res 23: 61-72

Briand MJ, Letourneur Y, Bonnet X, Wafo E, Fauvel T, Brischoux F, Guillou G, Bustamante P (2014) Spatial variability of metallic and organic contamination of anguilliform fish in New Caledonia. Environ Sci Pollut Res 21: 4576-4591

243 Cabidoche YM, Lesueur Jannoyer M (2011) Pollution durable des sols par la chlordécone aux Antilles: comment la gérer? Innovations Agronomiques 16: 117-133 
Cattan P, Cabidoche YM, Lacas JG, Voltz M (2006) Occurrence of runoff on high high infiltrability under two banana cropping systems. Soil Till Res 86:38-51

Chapman MR, Kramer DL (2000) Movements of fishes within and among fringing coral reefs in Barbados. Environ Biol Fishes 57: 11-24

Coat S, Bocquené G, Godard E (2006) Contamination of some aquatic species with the organochlorine pesticide chlordecone in Martinique. Aquat Living Resour 19: $181-187$

Cocheret de la Morinière E, Pollux BJA, Nagelkerken I, van der Velde G (2002) Postsettlement life cycle migration patterns and habitat preference of coral reef fish that use seagrass and mangrove habitats as nurseries. Estuar Coast Shelf Sci 55: 309-321

Dromard CR, Bodiguel X, Lemoine S, Bouchon-Navaro Y, Reynal L, Thouard E, Bouchon C (2016 a) Assessment of the contamination of marine fauna by chlordecone in Guadeloupe and Martinique (Lesser Antilles). Environ Sci Pollut Res 23: 73-80

Dromard CR, Bouchon-Navaro Y, Cordonnier S, Bouchon C (2016 b) The invasive lionfish, Pterois volitans, used as a sentinel species to assess the organochlorine pollution by chlordecone in Guadeloupe (Lesser Antilles). Mar Pollut Bull 107: 102-106

Epstein SS (1978) Kepone - Hazard evaluation. Sci Total Environ 9: 1-62

Glynn PW, Rumbold DG, Snedaker SC (1995) Organochlorine pesticide residues in marine sediment and biota from the Northern Florida Reef Tract. Mar Pollut Bull 30: 397-402

Haynes D, Johnson JE (2000) Organochlorine, heavy metal and polyaromatic hydrocarbon pollutant concentrations in the Great Barrier Reef (Australia) environment: a review. Mar Pollut Bull 41: 7-12

Haynes D, Muller J, Carter S (2000) Pesticide and herbicide residues in sediments and seagrasses from the Great Barrier Reef World Heritage Area and Queenland Coast. Mar Pollut Bull 41: 279-287

Huff JE, Gerstner HB (1978) Kepone: a literature summary. J Environ Pathol Toxicol 1: $377-395$

Luellen DR, Vadas GG, Unger MA (2006) Kepone in James River fish: 1976-2002. Sci Total Envion 358: 286-297

Nichols MM (1990) Sedimentologic fate and cycling of Kepone in an estuarine system: example from the James River estuary. Sci Total Environ 97/98: 407-440

Paez-Osuna F, Ruiz-Fernández AC, Botello AV, Ponce-Vélez G, Osuna-López JI, FríasEspericueta MG, López-López G, Zazueta-Padilla HM (2002) Concentrations of selected trace metals $(\mathrm{Cu}, \mathrm{Pb}, \mathrm{Zn})$, organochlorines (PCBs, HCB) and total PAHs in mangrove oysters from the Pacific Coast of Mexico: an overview. Mar Pollut Bull 44: $1296-1313$ 
281 Rato M, Sousa A, Quinta R, Langston W, Barroso C (2006) Assessment of inshore/offshore tributylin pollution gradients in the Northwest Portugal continental shelf using Nassarius reticulatus as a bioindicator. Environ Toxicol Chem 25: 99-106

284 Schaffelke B, Mellors J, Duke NC (2005) Water quality in the Great Barrier Reef region: responses of mangrove, seagrass and macroalgal communities. Mar Pollut Bull 51: 279-296

287 Wilkinson C, Salvat B (2012) Coastal resource degradation in the tropics: Does the tragedy of the commons apply for the coral reefs, mangrove forests and seagrass beds. Mar Pollut Bull 6: 1096-1105 


\section{Figures captions}

293 Fig. 1 Location of Guadeloupe in the Caribbean (a), location of the two study sites (b) and 294 location of the three habitats (M: mangroves, S: seagrass beds and R: reefs) in each study site 295

296 Fig. 2 Mean concentrations of chlordecone (all species included) in $\mu \mathrm{g} \cdot \mathrm{kg}^{-1}( \pm \mathrm{SE})$ measured 297 at Goyave and Petit-Bourg in mangroves, seagrass beds and coral reefs

299 Fig. 3 Mean concentrations of chlordecone by trophic groups (in $\mu \mathrm{g} \cdot \mathrm{kg}^{-1} \pm \mathrm{SE}$ ) measured at 300 Goyave in mangroves, seagrass beds and coral reefs. SM: suspended matter, Crust Det:

301 detritivorous crustaceans, Fish HB: herbivorous fishes, Fish PK: planktivorous fishes, Fish 302 CA1: carnivorous fishes 1, Fish CA2: carnivorous fishes 2 and Fish PV: piscivorous fishes 303

304 Fig. 4 Mean concentrations of chlordecone by trophic groups (in $\mu \mathrm{g} \cdot \mathrm{kg}^{-1} \pm \mathrm{SE}$ ) measured at 305 Petit-Bourg in mangroves, seagrass beds and coral reefs. SM: suspended matter, Fish CA1:

306 carnivorous fishes 1, Fish CA2: carnivorous fishes 2 and Fish PV: piscivorous fishes 


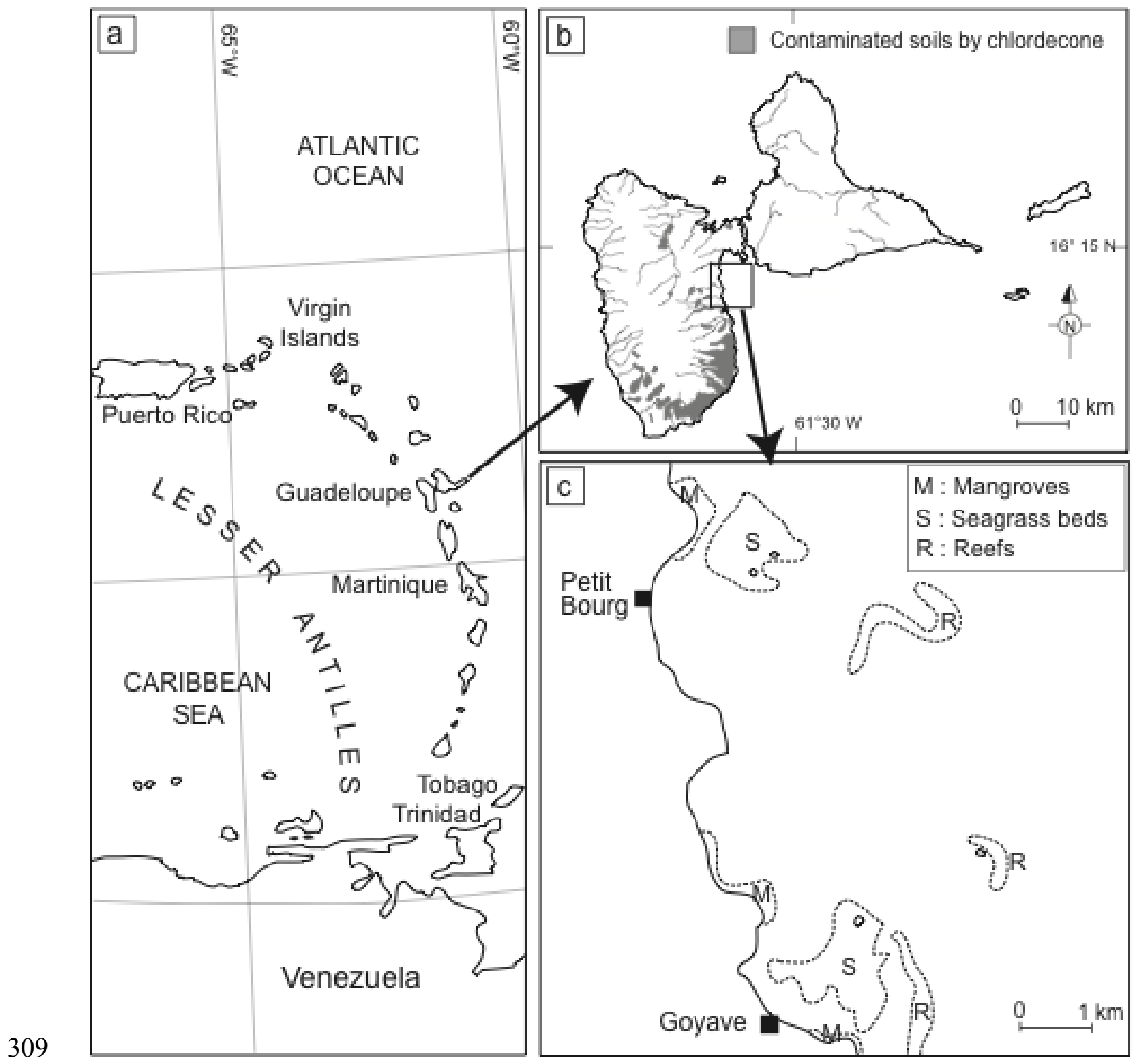



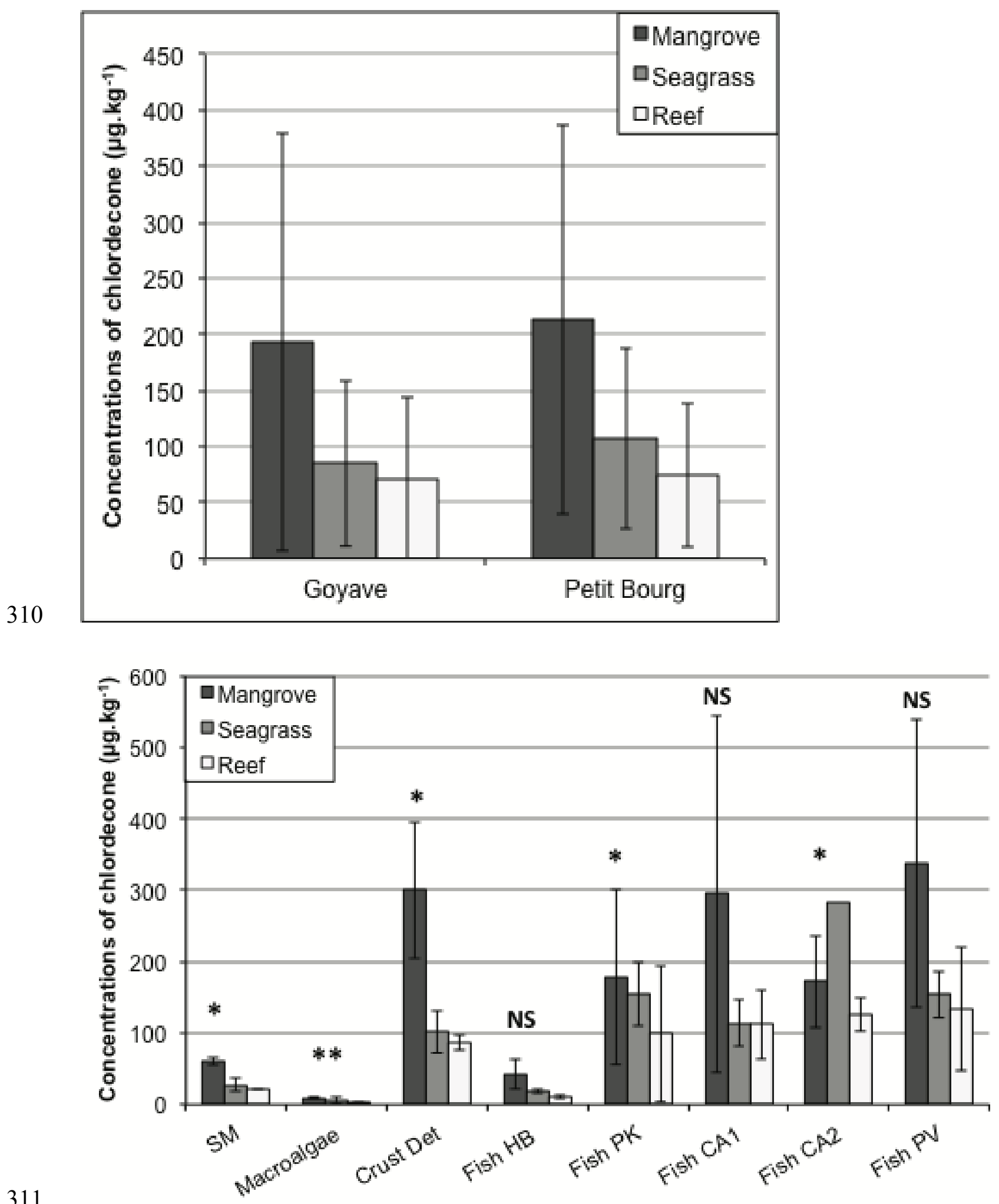


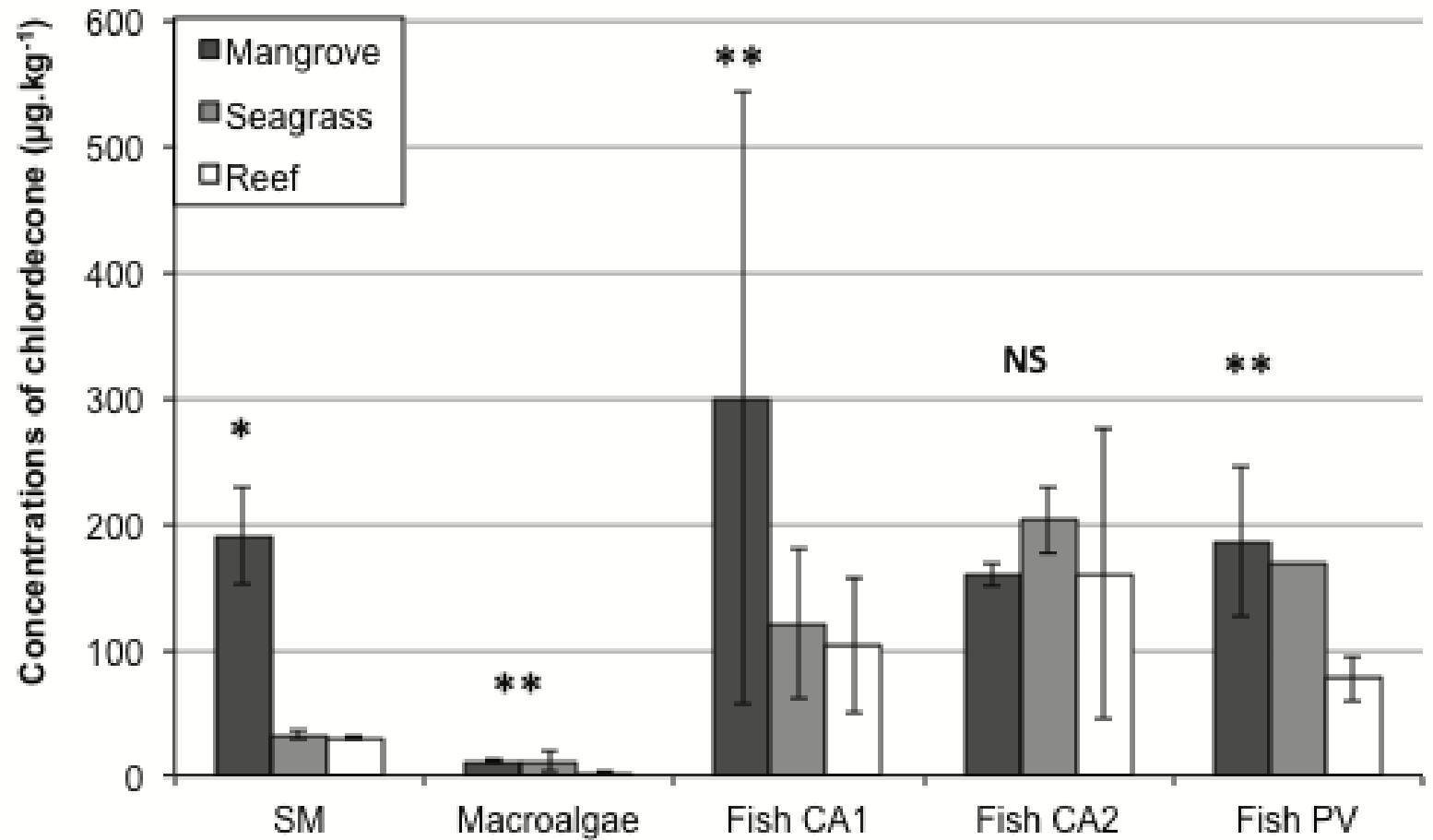

313

314 
315 Table 1 Mean concentrations of chlordécone in $\mu \mathrm{g} \cdot \mathrm{kg}^{-1}$ ( $\pm \mathrm{SE}$ ) of species and trophic groups collected 316 at Goyave. $\mathrm{n}$ is the number of samples.

\begin{tabular}{|c|c|c|c|c|}
\hline Samples & $\mathbf{n}$ & Mangrove & Seagrass bed & Coral reef \\
\hline Phytoplankton-SM & 9 & $60.0 \pm 5.6$ & $27.3 \pm 9.5$ & $20.7 \pm 0.6$ \\
\hline Suspended matter & 9 & $60.0 \pm 5.6$ & $27.3 \pm 9.5$ & $20.7 \pm 0.6$ \\
\hline Macroalgae & 21 & $8.6 \pm 1.3$ & $6.2 \pm 5.1$ & $1.8 \pm 0.7$ \\
\hline Acanthophora spicifera & 6 & $7.6 \pm 0.6$ & & $1.8 \pm 0.8$ \\
\hline Caulerpa sertularoides & 3 & & $10.7 \pm 2.0$ & \\
\hline Enteromorpha flexuosa & 3 & $9.6 \pm 0.8$ & & \\
\hline Galaxaura rugosa & 3 & & & $2.1 \pm 0.6$ \\
\hline Halimeda incrassata & 3 & & & $1.6 \pm 0.9$ \\
\hline Padina $\mathrm{sp}$ & 3 & & $1.8 \pm 0.3$ & \\
\hline Detritivorous crustaceans & 10 & $300.3 \pm 96.4$ & $102.0 \pm 29.7$ & $86.7 \pm 10.4$ \\
\hline Callinectes & 3 & $257.0 \pm 52.1$ & & \\
\hline Farfantepenaeus subtilis & 1 & 430.0 & & \\
\hline Panulirus argus & 6 & & $102.0 \pm 29.7$ & $86.7 \pm 10.4$ \\
\hline Herbivorous fishes & 9 & $42.0 \pm 20.3$ & $19.0 \pm 3.6$ & $10.3 \pm 3.2$ \\
\hline Scarus taeniopterus & 3 & & & $10.3 \pm 3.2$ \\
\hline Sparisoma radians & 6 & $42.0 \pm 20.3$ & $19.0 \pm 3.6$ & \\
\hline Planktivorous fishes & 14 & $177.9 \pm 122.0$ & $154.7 \pm 44.6$ & $99.0 \pm 95.5$ \\
\hline Anchoa lyolepis & 3 & $209.0 \pm 101.9$ & & \\
\hline Harengula clupeola & 3 & $113.0 \pm 72.5$ & & \\
\hline Hemiramphus balao & 4 & $228.5 \pm 228.4$ & $129.0 \pm 4.2$ & \\
\hline Heteropriacanthus cruentatus & 2 & & & $44.0 \pm 8.5$ \\
\hline Myripristis jacobus & 2 & & 206.0 & 209.0 \\
\hline Carnivorous fishes 1 & 24 & $295.4 \pm 249.8$ & $113.8 \pm 32.6$ & $112.3 \pm 48.9$ \\
\hline Eucinostomus gula & 3 & $100.7 \pm 14.6$ & & \\
\hline Eucinostomus lefroyi & 3 & & $91.3 \pm 11.0$ & \\
\hline Gerres cinereus & 1 & 207.0 & & \\
\hline Haemulon plumieri & 3 & & & $112.3 \pm 48.9$ \\
\hline Larimus breviceps & 1 & 522.0 & & \\
\hline Mulloidichthys martinicus & 1 & 204.0 & & \\
\hline Ocyurus chrysurus & 1 & & 145.0 & \\
\hline Polydactylus virginicus & 2 & $215.5 \pm 23.3$ & & \\
\hline Pomadasys corvinaeformis & 3 & $524.3 \pm 458.9$ & & \\
\hline Sphoeroides greeleyi & 5 & $254.3 \pm 196.6$ & $132.0 \pm 43.8$ & \\
\hline Trachinotus falcatus & 1 & 429.0 & & \\
\hline Carnivorous fishes 2 & 14 & $171.5 \pm 64.6$ & 284.0 & $126.4 \pm 23.6$ \\
\hline Bairdiella ronchus & 3 & $110.0 \pm 24.8$ & & \\
\hline
\end{tabular}




\begin{tabular}{lcccc}
\hline Gymnothorax funebris & 1 & 234.0 & & \\
Lutjanus apodus & 4 & 180.0 & & $123.7 \pm 32.3$ \\
Lutjanus griseus & 1 & & 284.0 & \\
Lutjanus mahogani & 1 & 275.0 & & \\
Lutjanus synagris & 3 & 146.0 & & $130.5 \pm 9.2$ \\
Rypticus saponaceus & 1 & 207.0 & & \\
Piscivorous fishes & $\mathbf{1 2}$ & $\mathbf{3 3 7 . 5} \pm \mathbf{2 0 1 . 5}$ & $\mathbf{1 5 4 . 0} \pm \mathbf{3 2 . 2}$ & $\mathbf{1 3 3 . 6} \pm \mathbf{8 7 . 1}$ \\
Aulostomus maculatus & 3 & & & $118.0 \pm 39.1$ \\
Caranx crysos & 3 & & $154.0 \pm 32.2$ & \\
Caranx latus & 1 & 480.0 & & \\
Pterois volitans & 3 & & & $87.7 \pm 26.1$ \\
Sphyraena barracuda & 1 & & & 318.0 \\
Sphyraena picudilla & 1 & 195.0 & & \\
All species pooled & $\mathbf{1 1 3}$ & $\mathbf{1 9 3 . 0} \pm \mathbf{1 8 5 . 5}$ & $\mathbf{8 4 . 8} \pm \mathbf{7 4 . 0}$ & $\mathbf{7 1 . 4} \pm \mathbf{7 2 . 4}$ \\
\hline
\end{tabular}

317

318

319 
320 Table 2 Mean concentrations of chlordécone in $\mu \mathrm{g} \cdot \mathrm{kg}^{-1}$ ( $\pm \mathrm{SE}$ ) of species and trophic groups collected 321 at Petit-Bourg. $\mathrm{n}$ is the number of samples.

\begin{tabular}{|c|c|c|c|c|}
\hline Samples & n & Mangrove & Seagrass bed & Coral reef \\
\hline Phytoplankton-MS & 9 & $191.3 \pm 38.5$ & $31.7 \pm 2.9$ & $30.3 \pm 2.1$ \\
\hline Suspended matter & 9 & $191.3 \pm 38.5$ & $31.7 \pm 2.9$ & $30.3 \pm 2.1$ \\
\hline Macroalgae & 15 & $11.3 \pm 0.6$ & $10.6 \pm 7.6$ & $2.3 \pm 1.1$ \\
\hline Acanthophora spicifera & 3 & $11.3 \pm 0.6$ & & \\
\hline Caulerpa sertularoides & 3 & & $16.6 \pm 6.0$ & \\
\hline Galaxaura rugosa & 3 & & & $1.4 \pm 0.7$ \\
\hline Halimeda incrassata & 3 & & & $3.2 \pm 0.5$ \\
\hline Padina sp & 3 & & $4.5 \pm 0.3$ & \\
\hline Carnivorous fishes 1 & 34 & $300.4 \pm 243.4$ & $121.0 \pm 59.8$ & $103.8 \pm 53.9$ \\
\hline Chaetodon capistratus & 2 & & $196.0 \pm 18.4$ & \\
\hline Eucinostomus argenteus & 3 & & $80.7 \pm 46.1$ & \\
\hline Eucinostomus gula & 6 & $202.3 \pm 12.9$ & $75.7 \pm 30.0$ & \\
\hline Eugerres brasiliensis & 1 & 861.0 & & \\
\hline Gerres cinereus & 3 & $182.5 \pm 145.0$ & 76.0 & \\
\hline Haemulon carbonarium & 4 & & & $89.5 \pm 33.9$ \\
\hline Haemulon flavolineatum & 3 & & & $66.3 \pm 12.3$ \\
\hline Haemulon plumieri & & & & \\
\hline Halichoeres radiatus & 2 & & & $188.5 \pm 10.6$ \\
\hline Ocyurus chrysurus & 3 & & $171.7 \pm 21.1$ & \\
\hline Pomadasys corvinaeformis & 1 & 121.0 & & \\
\hline Sphoeroides testudinum & 3 & $519.0 \pm 168.4$ & & \\
\hline Trachinotus falcatus & 3 & $131.3 \pm 21.4$ & & \\
\hline Carnivorous fishes 2 & 11 & $159.5 \pm 9.2$ & $203.3 \pm 26.0$ & $160.3 \pm 114.9$ \\
\hline Lutjanus apodus & 6 & & $196.3 \pm 28.0$ & $160.3 \pm 114.9$ \\
\hline Lutjanus griseus & 4 & 153.0 & $210.3 \pm 27.4$ & \\
\hline Rypticus saponaceus & 1 & 166.0 & & \\
\hline Piscivorous fishes & 23 & $185.6 \pm 58.9$ & 169.0 & $76.8 \pm 17.8$ \\
\hline Aulostomus maculatus & 3 & & & 83.0 \\
\hline Carangoides bartholomaei & 3 & $173.0 \pm 10.4$ & & \\
\hline Caranx crysos & 5 & $173.0 \pm 77.0$ & & $81.0 \pm 39.6$ \\
\hline Caranx latus & 4 & $180.3 \pm 81.3$ & & \\
\hline Pterois volitans & 3 & & & $74.3 \pm 11.7$ \\
\hline Sphyraena barracuda & 3 & 278.0 & 169.0 & 57.0 \\
\hline \multicolumn{5}{|l|}{ Sphyraena picudilla } \\
\hline Tylosurus crocodilus & 2 & 188.0 & & \\
\hline All species pooled & 92 & $213.1 \pm 173.6$ & $107.1 \pm 81.1$ & $73.7 \pm 64.1$ \\
\hline
\end{tabular}


322 